\title{
Biodegradation of sulphide in biogas by biofilm on salak fruit seeds: The effect of intra-film-gradient
}

\author{
Retno A. S. Lestari ${ }^{1, *}$, Wahyudi B. Sediawan ${ }^{2}$, and Sarto ${ }^{2}$ \\ ${ }^{1}$ Chemical Engineering Department, 17 Agustus 1945 University, Semarang, Indonesia \\ ${ }^{2}$ Chemical Engineering Department, Gadjah Mada University, Jl. Grafika 2 Yogyakarta 55281, Indonesia
}

\begin{abstract}
Elimination of $\mathrm{H}_{2} \mathrm{~S}$ in biogas was performed by bio-filtration, in which $\mathrm{H}_{2} \mathrm{~S}$ degrading bacteria immobilized on the packing material inside a column. Bacteria was taken from the local area, while salak fruit seed was used as packing material because it has a quite large carbon content, porous and has a high water absorption capability. To obtain a quantitative description of the process, which is useful in the design of large-scale bio-filters, two kinetics models were proposed. Model 1 assumes intra-film gradient does not exist and the gas phase is quasi-steady-state. Model 2 assumes intra-film gradient exists and the gas phase is quasisteady-state. Comparison of the calculation results using the two models to the experimental data suggested the use of model 2. This conclusion is based on both the trend and the accuracy. The trend of model 1 is more conceivable. However, for rough calculation, model 1 could be used for the reason that it is simpler than model 2. The average absolute errors of model 1 and 2 are comparable, approximately $6 \mathrm{ppm}$. It can also be concluded that intra-film gradient significantly affects the overall rate processes, while the gas phase can be assumed to be quasi-steady-state.
\end{abstract}

\section{Introduction}

One of the potential biomass-based materials for alternative energy is biogas. It is commonly derived from the anaerobic decomposition of organic substances such as animal waste, household waste, agricultural waste, waste water [1]. Biogas is a gas produced by fermentation of organic material by microorganisms in anaerobic condition. This anaerobic process follows the stages of the hydrolysis, asidogenesis and methanogenesis [2]. According to Syed et al. [3], biogas was composed of methane $\left(\mathrm{CH}_{4}\right)$ 55-70\%, carbon dioxide $\left(\mathrm{CO}_{2}\right)$ 30-45\% and hydrogen sulphide $\left(\mathrm{H}_{2} \mathrm{~S}\right) 0-1.5 \%$. Although the sulphide compounds contained in biogas are relatively small, they can be spoiling and even damage the equipment used on the utilization of biogas because it is corrosive [4].

Hydrogen sulphide removal process in biogas can be performed by physical and chemical processes such as absorption [5, 6] scrubbing [7], adsorption [8] and reactive absorption. Physical and chemical processes are costly and produce other waste.

Another way to remove sulphide compounds in biogas are biochemical conversion with bio-filtration method [9]. This process uses a bio-filter containing sulphide degrading bacteria immobilized on the surface of the packing material [10].

The use of salak fruit seeds for bio-filter media has never been done. Salak fruit seeds (SFS) easily absorb water, have a nearly uniform size, containing nutrition and are relatively hard. Furthermore their availability were abundant and cheap.

This research aims to eliminate sulphide compound contained in biogas using a bio-filter with SFS as packing material, and sulphide degrading bacteria taken from local area, as well as to get a kinetic model that could be used in designing a large scale system of sulphide elimination in biogas using bio-filter. Special focus in this study concerns with the effect of intra-film-gradient in the biofilm.

Studies on sulphide gas removal with bio-filters have been extensively conducted, but the use of salak fruit seeds as packing material have never be done. Studies on the removal of $\mathrm{H}_{2} \mathrm{~S}$ in biogas using a bio-filter with other packing materials, mostly focused on semi quantitative descriptive aspects, namely efficiency of removal (RE) of $\mathrm{H}_{2} \mathrm{~S}$ gas. Although there are researchers who studied quantitative descriptive, their approaches are still open for improvement.

This work is a quantitative descriptive study; the fundamental concepts of mass transfer and kinetics of biochemical reactions of sulphide compounds in the packed bed biogas are explored and laboratory experiments are also conducted to verify the kinetic model proposed.

Bio-filtration process is relatively simple. Gas containing $\mathrm{H}_{2} \mathrm{~S}$ was flowed through a pile of packing material which has a surface coated by pollutantdegrading bacteria as a biofilm [11]. Hence, sulphide is absorbed by biofilm, and oxidized by microorganism to

\footnotetext{
* Corresponding author: retnotengaran@gmail.com
} 
be elemental sulphur (if oxygen was limited) and $\mathrm{SO}_{4}{ }^{-2}$ (if oxygen is in excess) [12].

The packing material can be either organic or inorganic compounds. In selecting the support of bio-filter there are several criteria that must be fulfilled include nutrient content (source of $\mathrm{C}$ and $\mathrm{N}$ ), moisture content, $\mathrm{pH}$, porosity, ability to absorb contaminants, lightweight, and cheap [12,13].

Biofilms are microorganisms that attached and stick together in a polymer matrix [14]. The attachment of microorganisms on the surface of the packing material is very important for the initiation of the development of biofilm [15].

Sulphide-oxidizing bacteria include: bacteria of the genus Thiobacillus (kemoautotrof/ litotrof), green and purple sulfur bacteria (photoautotrophs), and types of heterotrophic include Atrhrobacter, Bacillus, Mikrococcus, Mycobacterium and Pseudomonas [16].

In this research used biogas, the observation to investigated hydrogen sulphide concentration at some axial position in the column at the various time at 1 phase. At the other paper, the research used the liquid solution of hydrogen sulphide and with difference conditions and difference model. Mathematical model proposed in other paper assumed no intra-film-gradient. [17].

\section{Mathematical models}

Some previous researchers who have done modelling in the process of gas and liquid waste handling using biofilters include Spigno et al. [18] in the elimination of phenol, Majumder et al. [19] in the process of removal of divalent copper dissolved in water, Jaber et al.[20] in modelling bio-filters for hydrogen sulphide contained in the air, Meena et al. [21] makes the mathematical modelling of the separation of a mixture of hydrophilic (methanol) and hydrophobic ( $\alpha$ Pinene), Santos et al. [22] used a mathematical model for the removal of hydrogen sulphide by oxidation in the bio-filter, Kim and Deshusses [23] calculate the mass transfer coefficient on the packing material used for bio-filter, either in the gas layer or the liquid layer. Furthermore Yang et al. [24] makes modelling of porosity variations of bio-filter equipment used in rotary drum, Ramirez et al. [25] studied the kinetics of microbial growth and biodegradation of methanol and toluene, De Visscher and Li [26] studied the disappearances modelling toluene contained in the air, Agarwal et al. [27] studied the mass balance for phenol degradation events. Modelling in this study was set-up by adopting and combining the basic ideas that emerged in previous studies.

The mathematical modelling of sulphide removal process with bio-filter columns proposed was based on the most fundamental concepts of mass transfer, phase equilibrium and kinetics of chemical reactions, and tried to avoid the use of special empirical equations. The solution of the mathematical equations formed is also based on common numerical methods, and avoiding special simplification. Two models were proposed with the objective to study the effects of intra-film-gradient to the rate of the overall process.

\subsection{Model 1}

Model 1 by Lestari et al. [28] assumes that biofilms are relatively thin, so there is no concentration gradient in the biofilm. Therefore the concentration of sulphide in the biofilm is uniform and the value is the same as the sulphide concentration at the surface of biofilm ( $\mathrm{Cs}=$ Csi). Furthermore, the sulphide concentration in the biogas flowing in the column is considered to be quasisteady-state.

In the model development, further following simplifications are applied:

1. The gas phase is plug-flow with no axial dispersion.

2. The biofilm is formed on the surface of the SFS only.

3. The thickness of the biofilm is relatively small compared to size of the SFS, so the geometry of the biofilm can be assumed as slab.

4. Biodegradation reaction occurs in the biofilm only, and follows Monod's type equation.

5. The biofilm thickness increases as time progresses.

6. The system is isothermal.

Sulphide material balance in the biofilm produces:

$$
\frac{\partial C_{S}}{\partial t}=\frac{k_{C}}{\delta}\left(C_{g}-C_{g i}\right)-r_{A}
$$

If the gas-bio-film equilibrium of sulphide follows Henry's type equation, then:

$$
C_{g i}=H_{S} * C_{S}
$$

The rate of biodegradation follows Monod's equation:

$$
r_{A}=\frac{\mu_{\max } C_{s}}{C_{s}+K_{S}}
$$

The thickness increase of the biofilm is caused by the the increase of the number of microbes, so:

$$
\frac{d \delta}{d t}=\frac{Y_{X}}{\rho} \cdot r_{A} \cdot \delta
$$

The material balance of the sulphide in the gas, assuming quasi-steady-state, gives:

$$
\frac{d C_{g}}{d z}=-\frac{k_{C} a_{S} S}{G}\left(C_{g}-C_{g i}\right)
$$

The models proposed were solved numerically by finite difference approximation as follows:

$$
\begin{gathered}
\left(C_{S}\right)_{j+1}=\left(C_{S}\right)_{j}+\frac{k_{C} \Delta t}{\delta}\left(\left(C_{G}\right)_{j}-H_{S}\left(C_{S}\right)_{j}\right)-\left(r_{A}\right)_{j} \\
\delta_{j+1}=\delta_{j}+\frac{A N}{\rho} r_{A} \delta_{j} \Delta t \\
\left(C_{G}\right)_{i+1, j}=\frac{\left(C_{G}\right)_{i, j}+\gamma \cdot H_{S} \cdot \Delta z \cdot\left(C_{S}\right)_{i+1, j}}{(1+\gamma \Delta z)}
\end{gathered}
$$




\subsection{Model 2}

Model 2 is the improvement of model 1, in which the biofilm is considered relatively thick, so the value of Cs in the biofilm is considered to be not uniform. Meanwhile the sulphide concentration in the biogas flowing in the column is considered to be quasi-steady-state.

The sulphide material balance in the volume element in the biofilm gives:

$$
\frac{\partial^{2} C s}{\partial x^{2}}-\frac{1}{D_{e}} r_{A}=\frac{1}{D_{e}} \frac{\partial C s}{\partial t}
$$

The rate of biodegradation is the same as equation (3) in model 1. The gas-bio-film equilibrium of sulphide follows Henry's type equation as equation (2). The material balance of the sulphide in the gas, assuming quasi-steady-state, is also the same as equation (5).

The thickness increase of the biofilm is caused by the increase of the number of microbes and can be calculated as follows:

$$
\int_{\delta_{0}}^{\delta} d \delta=\frac{Y_{x}}{\rho} \int_{X=0}^{X=\delta} r_{A} d x
$$

The models proposed were solved numerically by finite difference approximation.

$$
\begin{gathered}
\left(C_{G}\right)_{i+1, j}=\frac{\left(C_{G}\right)_{i, j}+\gamma \cdot H_{S} \cdot \Delta z \cdot\left(C_{S}\right)_{i+1, j}}{(1+\gamma \Delta z)} \\
\left(C_{S}\right)_{i, j+1}=\frac{\left(C_{S}\right)_{i-1, j}+(M-2)\left(C_{S}\right)_{i, j}+\left(C_{S}\right)_{i+1, j}}{M}-\Delta t \cdot\left(r_{A}\right)_{i, j}(12) \\
M=\frac{(\Delta X)^{2}}{D_{e}(\Delta t)} \ldots \ldots \ldots \ldots \ldots \ldots \ldots(\mathrm{i}=2,3,4, \ldots, \mathrm{N}) \\
\left(C_{S}\right)_{1, j+1}=\left(C_{S}\right)_{1, j}+\frac{2 k_{C} \Delta t}{\Delta x}\left(\left(C_{G}\right)_{j}-H_{S}\left(C_{S}\right)_{1, j}\right) \\
-\frac{2 D e \Delta t}{(\Delta x)^{2}}\left(\left(C_{S}\right)_{2, j}-\left(C_{S}\right)_{1, j}\right)-\Delta t\left(r_{A}\right)_{1, J} \\
\left(C_{S}\right)_{N+1, j+1}=\left(C_{S}\right)_{N, j}-\frac{2 D e \Delta t}{(\Delta x)^{2}}\left(\left(C_{S}\right)_{N+1, j}-\left(C_{S}\right)_{N, j}\right)_{(14)} \\
-\Delta t\left(r_{A}\right)_{N+1, J}
\end{gathered}
$$

If intra-film-gradient exists, the total sulphide degraded in the biofilm can be calculated by numerical integration as follows:

$\delta_{j+1}=\delta_{j}+\frac{A N}{\rho} \frac{\Delta x}{3}\left(\begin{array}{l}\left(r_{A}\right)_{0, J}+4\left(r_{A}\right)_{1, J}+2\left(r_{A}\right)_{2, J}+\ldots \\ +4\left(r_{A}\right)_{N, J}+\left(r_{A}\right)_{N+1, J}\end{array}\right)$

If the results of model 1 and 2 are not significantly different, it can be concluded that the effect of intra-filmgradient can be neglected. But for the opposite, the effect of intra-film-gradient is significant.

\section{Research Methodology}

\subsection{Materials}

Raw materials: salak fruit seeds for packing of bio-filter, sludge for source of sulphide degradation bacteria, biogas collected from Integrated Farming Unit, Agricultural Research and Development for Education (KP4) Facility, Gadjah Mada University.

Materials for nutrition: $\mathrm{KH}_{2} \mathrm{PO}_{4}, \mathrm{~K}_{2} \mathrm{HPO}_{4}$, $\mathrm{MgSO}_{4} .7 \mathrm{H}_{2} \mathrm{O}, \mathrm{CaCl}_{2}, \mathrm{FeCl}_{3} .6 \mathrm{H}_{2} \mathrm{O},(\mathrm{NH} 4)_{2} \mathrm{SO} 4$, and yeast extract [29].

Materials for analysis: $\mathrm{Zn}$-Acetic, $\mathrm{FeCl}_{3}$ and $\mathrm{N}, \mathrm{N}-$ Dimethyl-1,4-Phenylen Diamonium Diklorida solution, $\mathrm{MgCI}_{2} .6 \mathrm{H}_{2} \mathrm{O}, \mathrm{CH}_{3} \mathrm{COONa} .3 \mathrm{H}_{2} 0, \mathrm{CH}_{3} \mathrm{COOH}, \mathrm{BaCI}_{2}$, and aquadest.

\subsection{Research equipment}

The main equipment used in this research is the bio-filter packed column. The column for the bio-filter reactor was made of acrylic resin which has an inside diameter of 8.0 $\mathrm{cm}$ and a height of $100 \mathrm{~cm}$. The height of SFS packing was $80 \mathrm{~cm}$. The column has 6 port holes at different axial positions for taking samples to analyse sulphide concentration [18].

\subsection{Research Procedure}

The research procedures include: characterization of salak fruit seeds (SFS), immobilized bacterial cultures on SFS, isolation of bacteria, test of isolate to sulphide oxidation, test of biofilm formation of isolate on SFS, explorative study of isolates immobilized on seeds to degrade sulphide, characterization and identification of isolates superior (all of experimental data no shown in this paper), test of sulphide in biogas degradation in the bio-filter and mathematical modelling as well as testing the mathematical models to experimental data of sulphide elimination in the bio-filter.

\section{Result and Discussion}

Before being used in the bio-filtration process, after immobilization bacteria on the surface of the SFS, the colonies of bacteria on SFS surface was $1,56 \times 108$ $\mathrm{CFU} / \mathrm{ml}$, after being used for 8 hours in bio-filter process, it has $2.43 \times 109 \mathrm{CFU} / \mathrm{ml}$. This shows that during biofiltration process, the number of bacteria increased, caused by the growth and development of bacteria supported by nutrition from sulphide and nutrition in process bio-filtration [18].

\subsection{Elimination of sulfide of biogas in the biofilter}

The experiments of removal of sulphide in the biogas using a bio-filter containing the Bacillus cereus which forms biofilm on the surface of SFS operated at biogas flow rate of $30 \mathrm{~L} / \mathrm{h}, 48 \mathrm{~L} / \mathrm{h}, 66 \mathrm{~L} / \mathrm{h}$ and $84 \mathrm{~L} / \mathrm{h}$. The axial position observed of the inlet biogas are $0 \mathrm{~cm}, 20 \mathrm{~cm}, 40$ 
$\mathrm{cm}, 60 \mathrm{~cm}$ and $80 \mathrm{~cm}$. The sulphide concentration in biogas was varied from $10 \mathrm{ppm}$ to $180 \mathrm{ppm}$. The relationship between the sulphide concentration and RE versus axial position from gas inlet for biogas flow rate of $30 \mathrm{~L} / \mathrm{h}$ are shown in Figure 1.

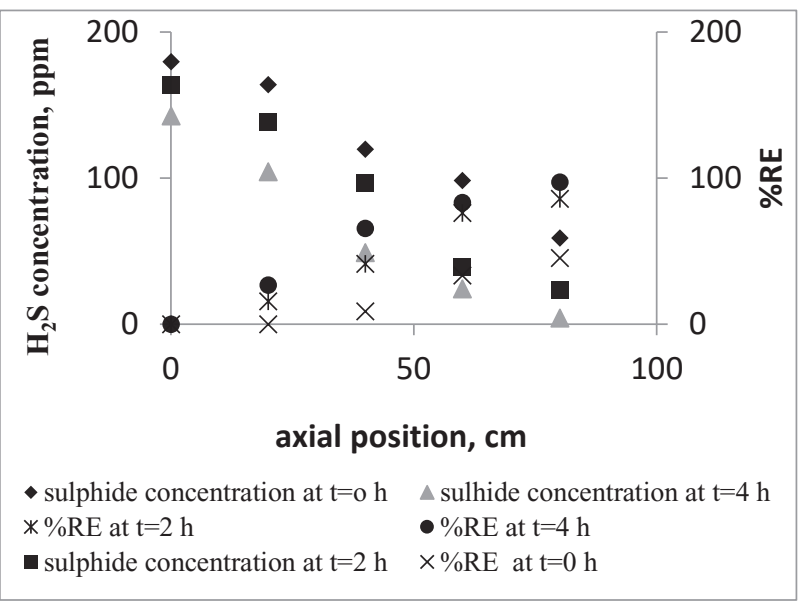

Figure 1. The relationship of the sulphide concentration and RE versus axial position at $\mathrm{Q} 30 \mathrm{~L} / \mathrm{h}$

From Figure 1, the influence of the axial position and operating time can be further discussed. The other figures of the relationship of the sulphide concentration and RE versus axial position at Q $48 \mathrm{~L} / \mathrm{h}, 66 \mathrm{~L} / \mathrm{h}$ and $84 \mathrm{~L} / \mathrm{h}$ are presented in Figure 2, Figure 3, and Figure 4. From those figures the influence of the biogas flow rate in the bio-filter could also studied.

\subsubsection{Effect of axial position}

$\mathrm{H}_{2} \mathrm{~S}$ removal efficiency will increase with the increasing distance from the bottom of the column. This happens as a larger distance from the bottom of the column will provide a longer contact time between the biogas and the biofilm, making the removal of $\mathrm{H}_{2} \mathrm{~S}$ more effective. In this packing column $(80 \mathrm{~cm}$ long and $8 \mathrm{~cm}$ inside diameter, thus $\mathrm{L} / \mathrm{D}=10$ ), the highest $\mathrm{H}_{2} \mathrm{~S}$ removal efficiency achieved was $97.15 \%$.

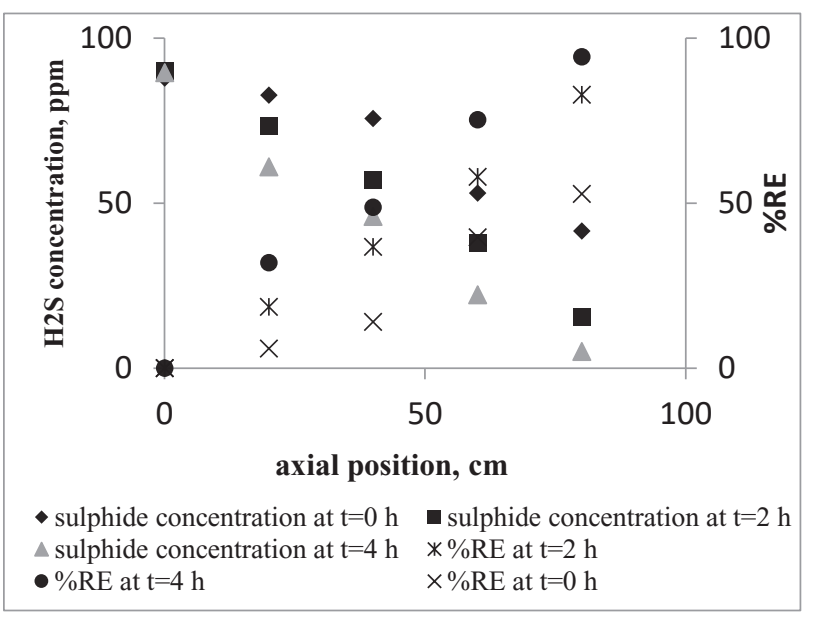

Figure 2. The relationship of the sulphide concentration and RE versus axial position at $\mathrm{Q} 48 \mathrm{~L} / \mathrm{h}$

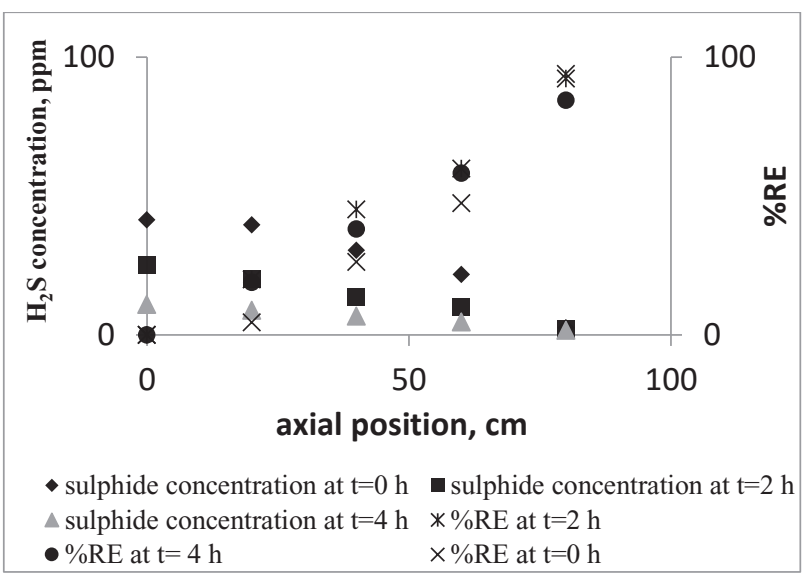

Figure 3. The relationship of the sulphide concentration and RE versus axial position at Q $66 \mathrm{~L} / \mathrm{h}$

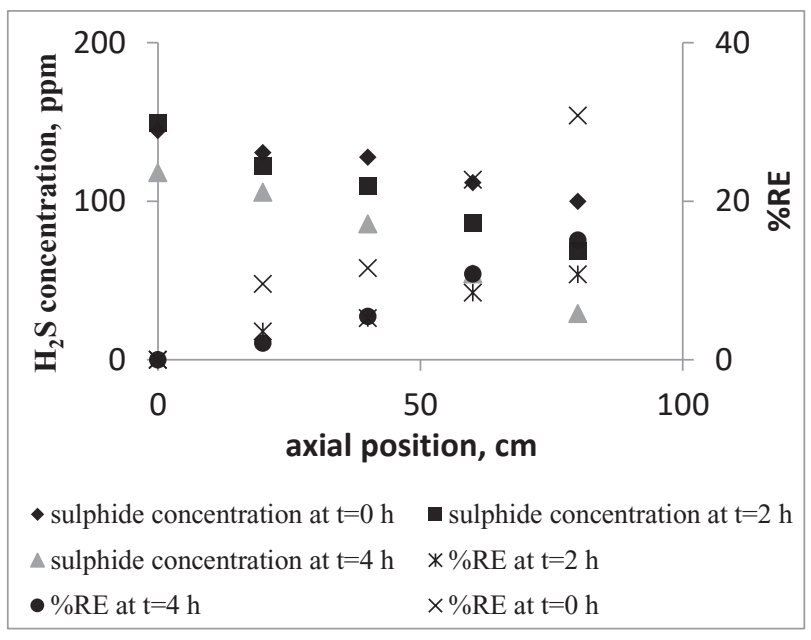

Figure 4. The relationship of the sulphide concentration and RE versus axial position at $\mathrm{Q} 84 \mathrm{~L} / \mathrm{h}$

\subsubsection{Effect of operation time}

The $\mathrm{H}_{2} \mathrm{~S}$ removal efficiency increase with the increasing time of operation, for different initial concentration of $\mathrm{H}_{2} \mathrm{~S}$ in biogas. This is conceivable since the biofilm grows on SFS surface throughout the column and a larger biofilm mass will consume more $\mathrm{H}_{2} \mathrm{~S}$, resulting in the higher $\mathrm{H}_{2} \mathrm{~S}$ removal. This microbial growth can be visually observed by the increase of the thickness of biofilm formed on the surface of the SFS.

\subsubsection{Effect of biogas flow rate}

The sulphide removal efficiency in a different position from the gas inlet indicates that the lower gas flow rate results in higher removal efficiency. This fact may be described as the following. As the gas flow rate increased, the contact time between $\mathrm{H}_{2} \mathrm{~S}$ and microorganism on SFS is shorter, thus only a smaller part of the $\mathrm{H}_{2} \mathrm{~S}$ could be degraded by the microorganism.

\subsubsection{The performance of SFS as a packing material} in the bio-filter 
The results of this study concluded that SFS can be used as packing material in the bio-filter for elimination of sulphide in the gas phase. It turned out that performance of SFS was comparable with others packing materials studied in the literature.

\subsection{Test of the mathematical modelling to experimental data of elimination of $\mathrm{H}_{2} \mathrm{~S}$ in biogas}

Simulations applying the two mathematical models proposed were performed using adjustable values of parameters involved until the results are close to the experimental data obtained. The comparison between the calculated results and the experimental data for the models are shown in Figure 5 and Figure 6. It can be observed that the calculation results using the two models are both close to the experimental data. It means that the two mathematical models proposed are adequate to quantitatively describe $\mathrm{H}_{2} \mathrm{~S}$ removal from biogas using biofilm on packed bed of SFS.

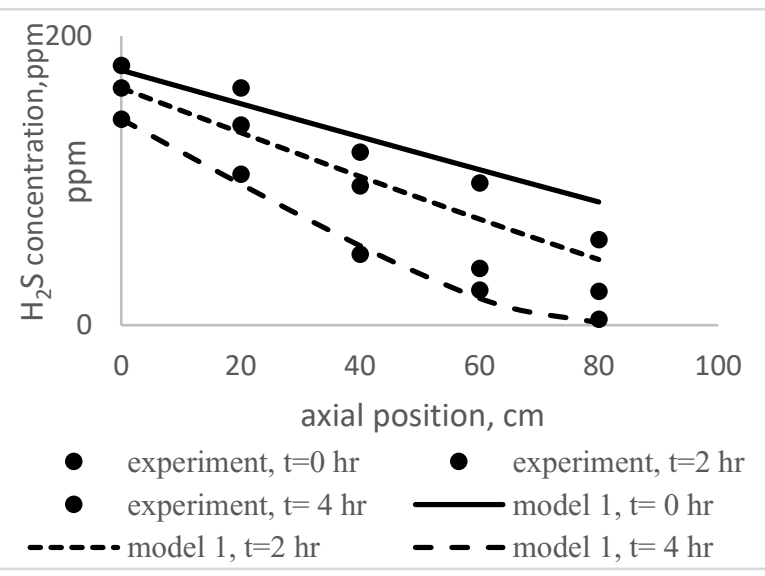

Figure 5. Comparison of modelling curve to data experiments of model 1

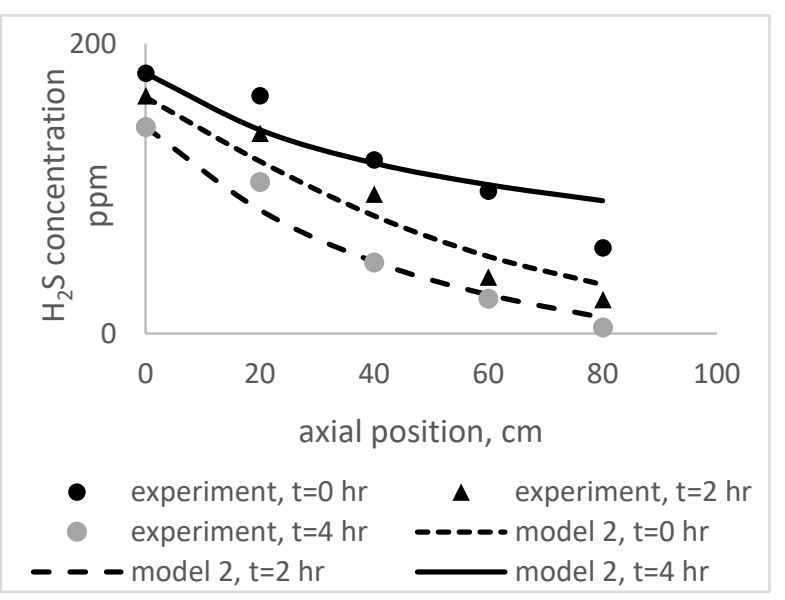

Figure 6. Comparison of modelling curve to data experiments of model 2

To be more comprehensively comparing the suitability of model 1 and model 2 to the experimental data, curves of model 1 and curves of models 2 were closely examined. The trends of the two curves are significantly different. Curves of model 1 are almost linear, while the curves of model 2 are non-linear. Logical interpretation of the process suggests that the curves of sulphide concentration versus time should be non-linear, because the sulphide concentration decreases due to biodegradation, resulting in the decrease of the rate of biodegradation. So, non- linear trend is more conceivable. As a consequence, model 2 is more conceivable than model 1. The average absolute errors of model 1 and model 2 are comparable, approximately $6 \mathrm{ppm}$. All in all, this comparison shows that even though both models have comparable accuracies, model 1 and model 2 are significantly different in the trends. Since the difference of model 1 and model 2 are on the consideration of intrafilm gradient, it can be concluded that the effect of intrafilm gradient needs to be considered.

Even though model 1 is inferior to model 2, but model 1 is still good enough to estimate the value of sulphide concentrations as well as the RE. The advantage of model 1 is the simplicity. It also needs simpler calculation. Time of calculation for model 2 is approximately four times to the one of model 1.

From model 1, it was obtained that: the maximum specific growth rate of bacteria $\left(\mu_{\max }\right)=9.3 \mathrm{E}-7 \mathrm{~s}^{-1}, \mathrm{~K}_{\mathrm{S}}=$ $4.0 \mathrm{E}-7 \mathrm{~g} \mathrm{~cm}^{-3}, \mathrm{H}_{\mathrm{S}}=0.7, \mathrm{Y}_{\mathrm{X} / \mathrm{S}}=60$, and mass transfer coefficient $\mathrm{a}_{0}=0.038$ and $\mathrm{a}_{1}=0.25$. Meanwhile for model 2 , the maximum specific growth rate of bacteria $\left(\mu_{\max }\right)=$ $1,8 \mathrm{E}-6 \mathrm{~s} \mathrm{~s}^{-1}$, half past saturation $(\propto)=8,0 \mathrm{E}-7 \mathrm{~g} \mathrm{~cm}^{-3}$, constant Henry $\left(\mathrm{H}_{\mathrm{s}}\right)=0.7$, yield $\left(\mathrm{Y}_{\mathrm{X} / \mathrm{s}}\right)=60$, effective diffusivity $(\mathrm{De})=2 \mathrm{E}-4$, and mass transfer coefficient $\mathrm{a}_{0}=0.0085$ and $\mathrm{a}_{1}=0.2$ for all flow rate.

\section{Conclusion}

This results of research can be concluded that the experiments of elimination of sulphide in biogas using bio-filter column shows that removal efficiency (RE) is affected by the axial position, operation time, biogas flow rate, and the concentration of $\mathrm{H}_{2} \mathrm{~S}$ in the gas input.

Based on the observation of the trends, it can be concluded that of the two mathematical models proposed, the recommended one is model 2 (assuming there is a gradient of concentration in the biofilm, the flow of gas in the bio-filter quasi-steady-state, the rate of degradation reaction follows Monod's type equation).

The accuracies of model 1 and model 2 are actually comparable since the average absolute errors for both models are approximately $6 \mathrm{ppm}$.

Comparison to experimental data shows that model 2 works well. For model 2, it was obtained that maximum specific growth rate of bacteria $\left(\mu_{\max }\right)=1.8 \mathrm{E}-6 \mathrm{~s}^{-1}$, half past saturation $(\propto)=8.0 \mathrm{E}-7 \mathrm{~g} / \mathrm{cm}^{3}$, constant Henry $\left(\mathrm{H}_{\mathrm{S}}\right)$ $=0.7$, yield $\left(\mathrm{Y}_{\mathrm{X} / \mathrm{S}}\right)=60$, effective diffusivity $(\mathrm{De})=2 \mathrm{E}-4$ $\mathrm{cm}^{2} \mathrm{~s}^{-1}$, and mass transfer coefficient $\mathrm{a}_{0}=0.0085$ and $\mathrm{a}_{1}=$ 0.2 for all flow rates.

Tests of mathematical models against experimental data of the elimination of sulphide in the biogas using a bio-filter containing Bacillus cereus bacteria on surface of SFS also indicate that intra-film-gradient needs to be considered, and the gas phase can be assumed to be quasisteady-state. 
Even though not considering intra-film gradient, so that less accurate than model 2, the simpler model 1 is good enough for rough calculation.

The authors would like to acknowledge to Directorate of Research and Technology of Higher Educations of Indonesia, for financial support of the research through research grant of Hibah Bersaing 2015 and Hibah Disertasi Doktor 2016.

\section{References}

1. H.R. Amini, D.R. Reinhart, Regional prediction of long-term landfill gas to energy potential. Waste Manage 31, 2020-2026 (2011).

2. Yadvika, T.R. Santosh, S. Sreekrishnan, Kohli, V. Rana, Enhancement of Biogas Production from Solid Substrates using Different Techniques - a Review. Bioresource Technology, 95, 1-10 (2004).

3. M. Syed, G. Soreanu, P. Falletta, M. Béland, Removal of hydrogen sulfide from gas streams using biological processes - a review, Can. Biosyst. Eng. 48 (2006) 2.1-2.14.

4. S. Pipatmanomai, S. Kaewluan, T. Vitidsant, Economic assessment of biogas to electricity generation system with $\mathrm{H} 2 \mathrm{~S}$ removal by activated carbon in small pig farm. Applied Energy, 86, 669674 (2008).

5. Boumnijel, H.B. Amor, H. Chekir, N. Hajji, Hydrogen sulphide removal from the effluents of a phosphoric acid production unit by absorption into chlorinated seawater under alkaline conditions, Comptes Rendus Chimie, xxx, 1-8(2016).

6. M. Taheri, A. Mohebbi, H. Hashemipour, A.M. Rashidi, Simultaneous absorption of carbon dioxide $\left(\mathrm{CO}_{2}\right)$ and hydrogen sulfide $\left(\mathrm{H}_{2} \mathrm{~S}\right)$ from $\mathrm{CO}_{2}-\mathrm{H}_{2} \mathrm{~S}$ $\mathrm{CH}_{4}$ gas mixture using amine-based nanofluids in a wetted wall column, J. Nat. Gas Sci. Eng. 28 (2016) 410-417

7. C.C. Lien J.L. Lin, C.H. Ting, Water Scrubbing for Removal of Hydrogen Sulfide $\left(\mathrm{H}_{2} \mathrm{~S}\right)$ Inbiogas from Hog Farms, Journal of Agricultural Chemistry and Environment 3, 1-6 (2014).

8. M.R.A. Al Mamun, S. Torii, Removal of Hydrogen Sulfide $\left(\mathrm{H}_{2} \mathrm{~S}\right)$ from Biogas Using Zero-Valent Iron, Journal of Clean Energy Technologies, 3, 6, 428-432, (2015).

9. C. Rattanapan, P. Boonsawang, D. Kantachote, Removal of $\mathrm{H}_{2} \mathrm{~S}$ in downflow GAC biofiltration using sulfide oxidizing bacteria from concentrated latex waste water, Bioresource Technology, 100 125-130 (2009).

10. Elias, A. Barona, A. Arreguy, J. Rios, I. Aranguiz, J. Penas, Evaluation of a packing material for the biodegradation of $\mathrm{H}_{2} \mathrm{~S}$ and product analysis, Process Biochemistry 37, 813-820 (2002)..

11. M.A. Deshusses, G. Hamer, and I.J. Dunn, Behavior of biofilters for waste air biotreatment. 1. Dynamic model development. Environ. Sci.Technol. 29. 14081458 (1995).
12. J.S. Devinny, M.A. Deshusses, and T.S. Webster, Biofiltration for air pollution control. Lewis Publishers. Boca Raton. 5-16 (1999).

13. M. Hirai, M. Ohtake, and M. Shoda, Removal Kinetic of Hydrogen Sulfide, Methanotiol and Dimethyl Sulfide by Pear Biofilter, Journal of Fermentation and Bioengineering (1990)

14. S. Craig, Microbiology: breaking down biofilm. Curr Biol;19:R132-4 (2002).

15. F.P. Chávez, F. Gordillo, C.A. Jerez, Adaptive responses and cellular behaviour of biphenyl degrading bacteria toward polychlorinated biphenyls. Biotechnol Adv 2006;24: 309-20 (2006).

16. P. Edmonds, Microbiology an environmental Perspective, Collier Macmillan Publisher. LondonNew York (1978).

17. R.A.S. Lestari, W.B. Sediawan and Sarto, Sulphide Removal from Liquid using Biofilm on Packed Bed of Salak Fruit Seeds, $2^{\text {nd }}$ International Conference on Engineering and Technology for Sustainable Development, Yogyakarta, 13-14 September (2017).

18. G. Spigno, M. Zilli, C. Nicolella, Mathematical modelling and simulation of phenol degradation in biofilters, Biochemical Engineering Journal 19 (2004).

19. S. Majumder, G. Gangadhar, S. Raghuvanshi, S Gupta, Biofilter column for removal of divalent copper from aqueous solutions: Performance evaluation and kinetic modeling Journal of Water Process Engineering 6 136-143 (2015).

20. M.B. Jaber, A. Couverta, A. Amranea, F. Rouxel, P. Cloireca, L.E. Dumontd, Biofiltration of H2S in airExperimental comparisons of originalpacking materials and modeling, Biochemical Engineering Journal 112, 153-160 (2016).

21. V. Meena, L. Rajendran, S. Kumar, P.G.J. Rani, Mathematical modeling of gas phase and biofilm phase biofilter performance, egyptian journal of basic and appliedsciences 3, 94-105 (2016).

22. J.M. Santos, E.S. Lopes, N.C.R. Junior, L. Melo de Sa, N.J. Horand, Mathematical modelling of hydrogen sulphide emission andremoval in aerobic biofilters comprising chemical oxidation, water research 43, 3355 - 3364 (2009).

23. S. Kim, and M.A. Deshusses, Determination of mass transfer coefficients for packing materials used in biofilters and biotrickling filters for air pollution control, Chemical Engineering Science 63, 841 - 855 (2008).

24. C. Yang, M.T. Suidan, X. Zhub, B.J. Kimc, G. Zeng, Effect of gas empty bed contact time on performances of various types of rotating drum biofilters for removal of VOCs, water research 42,3641-3650 (2008).

25. A.A. Ramirez, S. Bénard, A.G. Fendler, J.P. Jones, M. Heitz, Kinetics of microbial growth and biodegradation of methanol and toluene in biofilters 
and an analysis of the energetic indicators, Journal of Biotechnology 138, 88-95 (2008).

26. Visscher, A.D., Li, G.Q., 2008, Toluene removal biofilter modeling: Optimization and case Study, process safety and environment protection 86, 277282.

27. G.K. Agarwal, A.K. Ghoshal, Packed bed dynamics during microbial treatment of wastewater: Modelling and simulation, Bioresource Technology 99, 37653773 (2008).

28. R.A.S. Lestari, W.B. Sediawan, S. Syamsiah, and Sarto, Hydrogen sulfide removal from biogas using a salak fruit seeds packed bed reactor with sulfur oxidizing bacteria, Environmental Chemical Engineering Journal, 4, 2370-2377 (2016).

29. R.A.S. Lestari, W.B. Sediawan, S. Syamsiah, and Sarto, The Exploratory Study on Sulfide Removal Ability of Sulfur-Oxidizing Bacteria in Biofilm on Salak Fruit Seeds, International Proceeding of Chemical, Biological \& Environmental Engineering, Chemical Engineering and Applications V, Taipei, Taiwan, 16-19 (2014). 